\title{
Body suspension: performativita bolesti
}

\section{Body Suspension: Performativity of Pain}

\author{
Tomáš Kubart
}

\begin{abstract}
Abstrakt
Ve studii „Body suspension: performativita bolesti” se pokouším téma tělesného zavěšování (body suspension) předestřít v neprriliš problematizované podobě co nejširší odborné čtenářské obci, s ohledem na vlastní východiska, jež pramení především v teatrologii a dílčích otázkách teatrality a performativity (Fischer-Lichte, Judith Butler). V českém prostředí dosud odborně nereflektované téma vykazuje velmi zajímavé znaky, jež by měly upoutat každého divadelního vědce, antropologa, etnologa či kulturologa. Kontext a vzájemné souvislosti jednotlivostí fenoménu body suspension jsou natolik komplexní, že si jistě zasluhují první akademické texty. Má studie je kompilátem základních informačních zdrojů a vlastního výzkumu v českých a slovenských komunitách zabývajících se body suspension.
\end{abstract}

\section{Klíčová slova}

body suspension; tělesné zavěšování; mandanové; George Catlin; Fakir Musafar; Allen Falkner; Stelarc; performance; performativita; teatralita

\begin{abstract}
In the study the author strives to present the topic of body suspension to wide professional Czech public, to which it has been practically unknown, with regard to methodology of theatre and performance studies (Erika Fischer-Lichte, Judith Butler). The phenomenon bears a number of features interesting especially from the perspective of Theatre and Performance Studies, Anthropology, Ethnology, and Culturology. The study is supposed to attract interest of professional public to this complex phenomenon, presenting it with help of foreign secondary sources and the author's own research of Czech and Slovak body suspension communities.
\end{abstract}

\section{Keywords}

body suspension; Mandans; George Catlin; Fakir Musafar; Allen Falkner; Stelarc; performance; performativity; theatricality 
O Ódinovi se říká:

„Vím, že jsem visel

ve větrném stromu devět dlouhých nocí, oštěpem proklát v obět Ódinovi sám sobě samému."

(JUNG 2009: 143-144)

Napříč světovými kulturami rozličných civilizačních úrovní a okruhů se objevují podoby bolestivého rituálu, jehož účastníci jsou zavěšováni za probodnutou kůži: bezvládný staroseverský Ódin připomíná pravděpodobný průběh rituálu oběti u seveřanů a Germánů, další podobný rituál nalézáme u severoamerických indiánů (Mandanů, rituál okipa) nebo u sinhálských hinduistů, buddhistů a muslimů. Na většinu specifických podob rituálu, při němž dochází k probodnutí lidské kůže, za niž je posléze účastník vytažen vysoko nad zem a ponechán často i několik dní v závěsu, euroamerická civilizace doslova zapomněla. Dokud se neobjevil fenomén moderních primitivů, subkultury, jejíž členové aktivně odkrývali zapomenuté tradice a zvyky prvních předliterárních národů. $\mathrm{V}$ českém prostředí je fenomén body suspension, pod kterýmžto názvem si tento fenomén opět získal pozornost veřejnosti, i rituál okipa až na výjimky naprosto neznámý. Tato studie chce prostřednictvím teatrologického pohledu představit fenomén českému čtenáři. Z hlediska divadelní vědy je fenomén tělesného zavěšování trvale opomíjen. Studií se pokusím poukázat na důležité prvky, díky kterým si pozornost teatrologů zasluhuje podobně, jako si ji ve výzkumu teatrality získaly folklórní události.

Když americký umělec Roland Loomis přispíval v 80. letech 20. století pod jménem Fakir Musafar do Theatre Journal svými znepokojivými fotografiemi, na nichž pózoval na hácích z chirurgické oceli, znaly fenomén body suspension pouze komunity umělců body art, performance art a vznikající subkultura modern primitives. Díky Fakiru Musafarovi, Stelarcovi (Stelios Arcadiou) a umělcům performance artu a body artu se rituál „oh-kee-pa“ (okipa) missourského indiánského kmene Mandanů rozšíŕil jako „zavěšování na háky za lidskou kưži“ napříč společenskými vrstvami euroamerické kultury. Moderní pojetí body suspension upozad’uje původní náboženské a společenské významy, jež byly s rituálem spjaté, a nahrazuje je osobní zkušeností a prožitím nevšedního zážitku.

Body suspension (tělesné zavěšování) představuje extrémní formu body artu a jeho podmnožiny body modifications (tělesných modifikací), avšak z hlediska umělecké kategorizace je lze považovat za formu akčního umění. Jeho tvůrci nabízejí divákovi událost,

1 Akčni uměni, též akčni tvorba, je pojem užívaný v českém prostředí především v dějinách výtvarného umění zhruba od počátku devadesátých let minulého století. Jde o množinu zahrnující umělecké žánry, jež stojí na pomezí především divadelních a výtvarných, ale také hudebních či tanečních uměleckých forem. Pojem do českého uměnovědného prostředí zavedli Igor Zhoř (Akčni tvorba, Olomouc: Pedagogická fakulta Univerzity Palackého, 1991) a Pavlína Morganová (Akčni umění, Olomouc: Votobia, 1999). Tehdy zahrnoval body art, land art, happeningy, eventy, performance art, flash mobs a další vývojové větve, vyrůstající z inspirace výtvarným uměním, hudbou a divadelními formami. Takto, avšak bez použití jednotícího pojmu akční umění 
afekt, zážitek namísto artefaktu. Subkultury moderních primitivů (modern primitives) ${ }^{2}$ a $\mathrm{BDSM}^{3}$ přejaly v šedesátých až osmdesátých letech minulého století v rámci obnovování iniciačních rituálů část starého rituálu severoamerického indiánského kmene Mandanů, a tak jsou praktiky tělesného zavěšování v tomto období spojeny téměř výlučně s jejich komunitami. Teprve v devadesátých letech došlo k rozšíření zmíněných praktik mezi širší veřejnost, $\mathrm{k}$ čemuž přispěly také starší filmy A Man Called Horse (Muž zvaný Kůň; r. Elliot Silverstein, 1970) a Dances Sacred and Profane (Tance posvátné a světské; r. Mark Jury, 1987), v nichž se tělesné zavěšování objevuje a jejichž obliba stoupla s popularitou Fakira Musafara.

Musafar se stal prvním známým představitelem euroamerické civilizace, který se pokusil o napodobení části rituálu okipa (angl. o-kee-pa, něm. Okippe) a re-enactment závěsu ${ }^{4}$. Od útlého věku se zabýval rưznými formami tělesných modifikací a z počátku hledal inspiraci v cestopisné literatuře, především ve fotografických reportážích časopisu National Geographic. Lze si jen domýšlet, proč se Musafar ve svém bádání zaměřil převážně na kulturu prvních národů, v důsledku čehož mu zřejmě unikly informace o tom, že rituál podobného provedení realizovali také sinhálští muslimové, hinduisté i buddhisté na Srí Lance (Kataragama: A God for All Seasons 1973), a proč se jejich pojetí v době vstupu tělesného zavěšování do euroamerické kultury neobjevilo v ohnisku Fakirova zájmu. Při sledování procesu akulturace tělesného zavěšování se zaměříme pouze na verzi mandanskou, protože proces kulturní apropriace rituálního zavěšování na háky vycházel z tradice mandanské, nikoliv sinhálské.

\section{Mandanský bizoní tanec: rituál okipa}

Mandanové obývali břehy řek Missouri, Heart River a Knife River v dnešní Severní a Jižní Dakotě (srov. LOWIE 1913). Jejich jazyk patří do rodiny jazyků siousko-katóbských ${ }^{5}$,

(Aktionkunst, action art), sjednotili výše uvedené kategorie také Allan Kaprow, americký teoretik happeningu, ve své knize Assemblage, Environments and Happenings (New York: H. N. Abrams, 1966), ale také Adrian Henri (Total art: environments, happenings, and performance. München: Praeger Verlag, 1974) či Jindřich Chalupecký (Na hranicích uměni. Praha: Prostor, 1990).

2 Modern primitives je označení subkultury post-koloniálních národů, angažujících se v oblasti body modification. Typické jsou pro ni kulturní apropriace a jejich vzájemné mísení: přechodové rituály s různými formami tetování, skarifikace, brandingu (skarifikace aplikací horkého materiálu, obvykle kovu, z vážného popálení vzniká hojením trvalá jizva) či cuttingu (jeden z nejběžnějších typů skarifikace [řezání]).

3 BDSM je zkratkou slov „bondáž“, „disciplína“, „sadismus“ a „masochismus“ (resp. BD: bondage and discipline, DS: dominance and submission, SM: sadism and masochism). Poprvé byl použit v diskuzním systému Usenet roku 1991. Jde o označení škály erotických praktik zahrnujících bondáž, dominanci, submisi, sadomasochismus a další interpersonální dynamiky.

4 „Závěs“ je pojem, kterým členové jedné z nejvýznamněǰších českých skupin (studio Hell) běžně označujî okamžik, v němž je viselec vytažen za háky nad podložku. „Zavěšování“ označuje samotnou činnost, opakovanou praxi.

5 Siusko-katóbské jazyky jsou středně velkou rodinou indiánských jazyků Severní Ameriky. Zahrnují především tradiční rodinu siuských jazyků, rozšîřených původně především ve vnitrozemí USA, a dnes již vymřelé katóbské jazyky z východního pobřeží. 
Mandanové žili zemědělským způsobem života a sami sebe nazývali See-pohs-ka-nu-mah-kā-kee ${ }^{6}$, tj. „bažantí lid“ (CATLIN 1867). Obchodovali s jinými kmeny prérijních indiánů, především s Crowy a Hidatsy, s nimiž byli v první třetině 19. století sestěhováni do jedné vesnice a provozovali s nimi společně rituál okipa. Okipa znamená „vypadat stejně“ a odkazuje k mužským mandanským tanečníkům, kteří jsou oblečeni a pomalováni tak, aby připomínali zvířata. Obřad je rozvinutím pradávného rituálu bizoního tance ${ }^{7}$, jenž zpřítomňuje tři mýty: stvoření Mandanů, příběh vysvobození zvířat Osamělým mužem (Nu-mohk-muck-a-nah) (DEMALLIE a STURTEVANT 2001: 577) z hory Dog Den Butte, čímž bylo odvráceno vypuknutí hladomoru mezi Mandany, a záchranu Mandanů Osamělým mužem před potopou na velké kánoi, kterou evropští cestovatelé považovali za obdobu starozákonní archy. ${ }^{8}$ Proto se také ceremonie odehrává v období, kdy rozkvétají vrby: „Větvička, již přinesl pták do Velké kánoe, byla vrbová, a obsypána listy. "9 (CATLIN 1967: 15)

Obřad byl prosbou představitelů kmene k Osamělému muži, aby do blízkosti vesnice přivedl stáda bizonů a zajistil tak dostatek potravy pro kmen. Nejvyšší bytost mandanské mytologie, První Stvořitel, navštívila Mandany se svým synem, Osamělým mužem. V tom čase však Hoita uvěznil bizony a veškerou lovnou zvěř na hoře Dog Den Butte. Osamělý muž se na horu vplížil v přestrojení za králíka a spatřil, že zviŕata se oddávají zvláštnímu druhu tance. Naučil se písně a kroky tance a instruoval Mandany, aby ceremoniál opakovali podle zvírecího tance. Zlý duch Hoita ceremonii sledoval a osvobodil všechnu zvěř. Závěs vybraných adeptů znamenal akt oběti, která měla prospět celému společenství. Byl kombinací náboženských (BELLIGER a KRIEGER 2013: 113) a přechodových rituálů; a obsahoval prvky praktické magie (BELLIGER a KRIEGER 2013: 127). ${ }^{10}$

6 Mandanské výrazy přepisuji v anglické či v německé transkripci podle literárního zdroje, z něhož jsem pro studii čerpal (většinou tedy CATLIN; BOWERS a WIED-NEUWIED).

7 Ivana Pantělejevová uvádí, že obřad okipa byl „částí obřadu zvaného Tanec slunce“ (PANTĚLEJEVOVÁ 2013: 42). Ačkoliv rituál zřejmě nese znaky, pro něž je takto označován (hlavní mytologická postava Osamělého muže prochází vesnicí za úsvitu; rituál se koná v období letního slunovratu), navíc nese i formální znaky podobnosti s fenoménem tance slunce, je okipa spíše specifickým obřadem a nelze jej ztotožňovat s obřadem tance slunce Lakotů, Čejenů nebo Komančů.

Autoři Dictionary of American History uvádějí na pravou míru podobnost okipa s rituály ostatních kmenů velkých prérií: „Ústřední rituál Mandanů, okipa, nebyl tancem slunce ale spíše komplexní ceremonií [...].“ Viz „Sun Dance“. Dictionary of American History.

Libenská uvádí: „S tancem slunce úzce souvisel rituál okipa Mandanů.“ (LIBENSKÁ 2009: 74) „Tanec slunce bývá mezi Lakoty praktikován zasunutím ostré dřevěné špice do kůže na hrudi a přivázáním obou jejích konců k lanu, jež je přimknuto ke stromu. Tanečníci po dlouhou dobu visí v závěsu a vykonávají prudké pohyby směrem od lana a celou vahou svého těla se pokoušejí kůži na hrudi protrhnout. Zdá se, že okipa je mandanským rozvinutím rituálu tance slunce." (LIBENSKÁ 2009: 74)

8 Mandanové jsou jediným severoamerickým indiánským kmenem, v jehož legendách se objevuje velká potopa, podobná té starozákonní. Není jasné, zda jde o původní mýtus, nebo Mandany inspirovali misionáři, kteří k nim snad kdysi dospěli.

$9 \quad$ Překlady německých a anglických částí provedl autor studie.

10 „Pojem magie, jak je užíván v následujícím textu, se nevztahuje pouze na rituály jiných národů, nýbrž taktéž na naše vlastní. Nejedná se o negativní termín, ale spíše o označení rituálu, který má mít nějaký účinek. Pojem odkazuje na určité rituální prvky, které vedou k cíli. Pokud není rituál pouhým jednáním s prvky transcendence a vykazuje požadované empirické výsledky, lze jej nazývat magickým." (BELLIGER a KRIEGER 2013: 127) 
Ceremonie, prováděná $\mathrm{v}$ mandanském dialektu nuptadi, ${ }^{11}$ se odehrávala $\mathrm{v}$ obřadní chýši ${ }^{12}$ okipa a na kruhové návsi o průměru asi sto padesát metrů, obklopené zemnicemi. Uprostřed otevřeného ${ }^{13}$ kruhu stál posvátný cedrový sloup minimi tahEdE, tj. ústup vod. Chýše symbolizovala horu Dog Den Butte, ve které Hoita uvěznil všechny živoucí tvory a jejímž správcem byl muž z klanu WaxikEna. Hlavními postavami obřadu byli Osamělý muž, Kropenatý orel (Hoita) Kauih-Sāchka (hlavní ceremoniář, anglická transkripce Ka-See-Ka) ${ }_{1}^{14}$ Modrá volavka (muž vybraný z ceremoniárưo, jenž sledoval mlčky zpovzdálí celý obřad), zpěváci, osm bizoních tanečníků a různý počet postících se kandidátů. Obřad okipa byl čtyřdenní ceremonií kmene a zavěšování na háky za kủži bylo její liminální ${ }^{15}$ fází, jež se konala třetího dne. První dva dny se komunita připravovala na vrchol rituálu písněmi za doprovodu bubnů z želvích krunýřů. Půst začínali kandidáti (viselci) držet již čtyři dny před prvním obřadním dnem a drželi jej až do dne posledního. Třetí den byli kandidáti po sedmidenním půstu v chýši okipa vytaženi na lanech a tato fáze byla snad (podle BOWERSE 1950) opakována také posledního dne rituálu (podle WIED-NEUWIEDA 1839, jsou toho dne viselci pouze pořezáni).

Třetího dne ceremonie každý adept požádal muže z klanu svého otce, aby mu probodl kůži na místech závěsu. Kůží na zádech v oblasti lopatek nebo na hrudi byly protaženy ostré dřevěné jehlice a za ně byli kandidáti vytaženi provazy, upevněnými ke sloupu obřadní chýše okipa. Další jehlice byly protaženy kůží na stehnech a na ně byly navěšeny bizoní lebky. Zatímco bizoní tanečníci tančili př̌ed chy̌ší, podstoupil závěs první viselec. S každým návratem tanečníka do chýše byl zavěšen další kandidát. Muži i ženy pak procházeli kolem viselců, tahali je za končetiny nebo roztáčeli jejich malátná a vyhladovělá těla, jež se míhala ve svitu ohňů ve stále zrychlujícím se tempu bubeníků a obřadních zpěvů. Aby podpořil pravdivost svědectví jednoho z prvních nepůvodních obyvatel Severní Ameriky, jenž byl rituálu přítomen, popsal roku 1860 tuto liminální fázi rituálu poručík páté dobrovolnické divize na Fort Laramie, Henry E. Maynadier:

Dřevěná jehlice o délce deseti centimetrů byla na jedné straně hrudníku protažena dvěma otvory v kůži, a na obou jejích koncích byla uchycena smyčka z jednoho ze dvou provazů. Druhý provaz byl připevněn stejným zpơsobem na druhou stranu hrudníku a nebožák byl vyzdvižen na nohy. Bubeníci rozduněli bubny a mladý muž sebou prudce trhl zpět, nesouce celou svou váhu na provazech, houpajíce se kolem úpatí sloupu. Kůže byla vytažena o několik palců [...] a nebožák omdlel a bezvládně visel v závěsu. (CATLIN 1967: 27)

11 Též nephtali (srovnej MERTZ 1957: 107), nářečí klanu Mandanů.

12 Chýše byla rozdělena do dvou polovin. Levá polovina př́slušela klanům Prérijních kuřat, Kropenatým orlům a pěti dalším klanům. Pravá strana připadla klanům WaxikEna, Tamisik, Tamixixikům a třem dalším klanům jejich poloviny (BOWERS 1950: 407).

13 K jihu byl kruh zemnic otevřený, aby mohl vejít Osamělý muž. Vchod chýše okipa byl také obrácen $\mathrm{k}$ jihu.

14 V roce 1834, který popisuje Wied-Neuwied, jím byl náčelník Mató-Tópe (WIED-NEUWIED 1839: 171).

15 Liminální, přechodová fáze rituálu. Liminální rituál, nebo liminální fáze rituálu představuje změnu statutu pro individuální osobu nebo sociální skupinu, která probíhá v čase. Více viz (GENNEP 2013: 208). 
Hlavní účel rituálu spočíval v zachování budoucnosti kmene. Ta závisela na blízkosti bizoních stád a určovala se důsledným výkladem vizí zmožených viselců. Jakmile viselec ztratil vědomí, vynesli ho ostatní účastníci před chýši a v bezvědomí byl ponechán svým představám, které vznikaly následkem totálního vyčerpání. Mandanové věřili, že právě v těchto momentech bývají vize nejsilnější a nejbohatší. Spatřené obrazy kandidáti interpretovali spolu s kmenovými staršiny a zasvěcený výklad měl zajistit kmeni budoucnost. Opakování rituálu mělo kmeni zaručit, že Hoita znovu nezakleje lovnou zvěř v lesích hory Dog Den Butte, také proto Ka-See-Ka prosí Osamělého muže, aby přivedl stáda $\mathrm{k}$ mandanské vesnici.

Body suspension ve své současné podobě je pokusem některých subkultur o napodobení tohoto několik staletí starého ${ }^{16}$ rituálu dakotských Mandanů, jak byl prokazatelně prováděn ještě v první polovině 19. století (konkrétně jeho liminální části závěsu). Ačkoli k prérijním Mandanům pronikli již roku 1738 francouzští bratř̌i Vérendryeovi ${ }^{17}$ a kolem roku 1804 slavná výprava Lewise a Clarka, výzkumem jejich zvyků se zabývali až od třicátých let 19. století především německý šlechtic Wied-Neuwied, newyorský malîr Catlin a americký archeolog Bowers. Prvním Evropanem, jenž zvyk v poslední mandanské vesnici Mih-tutta-hang-kusch (Víska jako rybářský háček) zaznamenal, avšak neúčastnil se ho př́mo, byl roku 1832 Maximilian zu Wied-Neuwied ${ }^{18}$ (1782-1867). V knize Reise in das innere Nord-America in den Jahren 1832 bis 1834 (Cesta do vnitřní Severní Ameriky v letech 1832-1834, 1837-1841), ${ }^{19}$ popsal liminální fázi ceremonie následovně:

Nyní započalo se kajícníkům mučení, z hrudi či z ramen jsou jim řezány pásy kůže i masa, také ze zad, avšak takovým způsobem, že zůstávali na obou koncích připevněni, vytaženi řemeny a vrhali se nad příkrou stráň pod vesnicí, kde pak byli volně zavěšeni ve vzduchu, dalším byly na řemenech do ran zavěšeny bizoní lebky a viselci museli tyto těžké hlavy vláčet za sebou, ještě další se nechali vyvěsit za zádové svaly, dalším byl odseknut článek prstu, ještě další byli konečně vyzdviženi do výšky za maso odřezané nad žaludkem, nebo byla jejich těžká těla zavěšována za odřezané svaly, a podobně. (WIED-NEUWIED 1839: 27)

16 John C. Ewers v reedici díla George Catlina (1967) uvádí, že v době Catlinova pozorování rituálu (1832) mohl mít rituál za sebou až sedmisetletou historii.

17 Bratři Louis-Joseph Gaultier de la Vérendrye (podle některých zdrojů [Ewers] Pierre Gaultier de Varennes de Vérendrye) a Francois de la Vérendrye byli prvními Evropany, kteř́i přešli severní Velké pláně a spatřili Rocky Mountains v letech 1742-1743. O jejich cestě toho není př́liš známo, dostupné informace pochází z francouzských novin, nalezených v archívech roku 1851. Hory, které bratři prošli, byly pravděpodobně Big Horn Mountains ve Wyomingu, ale také mohlo jít o Black Hills nebo Laramie Mountains.

18 Princ byl titulem propůjčovaným německé šlechtě herzogů, landgrafů, platzgrafů, margrafů a knížat. Maximilian Alexander Philipp zu Wied-Neuwied cestoval pod pseudonymem Baron von Braunsberg spolu s malîřem Karlem Bodmerem (1809-1893). Byl nástupcem knížecího postu knížectví Wied (od roku 1784), německým etnologem, zoologem a přírodovědcem.

19 V Neuwiedově 2. svazku o putování po Severní Americe je na stranách 638-667 také převzatý popis rituálu okipa od Catlina (Catlin's Beschreibung des Festes Okippe). Wied-Neuwiedova kniha vyšla také v angličtině jako Maximilian Prince of Wied's Travels in the Interior of North America, during the years 1832-1834 (1843-1844) a ve francouzštině jako Voyage dans l'interieur de L'Amérique du Nord exécuté pendant les années 1832, 1833 et 1834 (1840-1843). 
Z jeho zápisu je čitelné, že obřadu osobně přítomen nebyl a poskytuje pouze zprostředkovaný popis rituálu, jehož závěsová (zavěšovací) fáze se ve skutečnosti neodehrávala „nad př́́krou strání pod vesnicí“, ale v obřadní chýši. Wied-Neuwiedovým současníkem byl americký malíŕ, spisovatel a cestovatel George Catlin (1796-1872), ${ }^{20}$ který rituál okipa jako první představitel euroamerické civilizace nejen popsal, ale také na vlastní oči sledoval $^{21}$ a své poznatky zveřejnil nejprve v novinách (1833), později pak v publikaci $O-k e e-p a$ : A religious ceremony and other customs of the Mandans (Okipa: náboženský obřad a další zvyky Mandanů, 1867). Catlin spatřil rituál o dva roky dříve (1832) než Wied-Neuwied (1834) a je pozoruhodné, jak moc se liší v jeho výkladu: zatímco Catlin se ve výkladu přiklání k legendě o Osamělém muži, který Mandany zachránil rituálním tancem, Wied-Neuwied se přiklání k výkladu, podle něhož je rituál zpřítomněním mýtu o velké potopě a mandanské arše. Wied-Neuwied však možná opomíjí, že tato legenda se mohla stát součástí mandanských mýtů až po příchodu prvních misionářu do oblasti velkých prérií. Ačkoliv pravdivost ${ }^{22}$ Catlinova děsivého a pro jeho současníky jen stěží uvěřitelného vyprávění napadlo několik autorit (především obchodní komisař Mitchell ${ }^{23}$ a pro-otrokářský geograf Schoolcraft), ${ }^{24}$ jeho věrohodnost potvrdil roku 1872 tlumočník z mandanštiny a významný agent kožešinových společností James Kipp ${ }^{25}$ i další nezávislí pozorovatelé. V padesátých letech 20. století již neprovozovaný rituál popsal na základě Catlinova pozorování a za pomoci mandanského informátora americký archeolog Andrew W. Bowers ${ }^{26}$ (19011990), autor publikací Mandan Social and Ceremonial Organization (Mandanská sociální a ceremoniální organizace, 1950) a Hidatsa Social and Ceremonial Organization (Sociální

20 George Catlin se specializoval na portréty severoamerických indiánů. Na americký západ cestoval ve 30. letech 19. století celkem pětkrát a stal se prvním bělochem, který popsal život prérijních indiánů.

21 „[...] okipa, jehož byl svědkem uprostřed léta 1832 na otevřeném náměstí a ve velké obřadní chýši na náměstí uprostřed mandanské vesnice.“ (CATLIN 1967: 2)

$22,[\ldots]$ ve svém popisu nebo ilustracích nepředstavuji nic, než co jsem viděl, a že jsem měl po svém boku, v průběhu čtyř dnů těchto scén, tři civilizované a vzdělané muže, kteří mi dali svá prohlášení, že byli spolu se mnou svědky těchto scén, jak jsem je prezentoval, a jejichž certifikáty, jakož i další důkazy, budou vydány na náležitých místech, jak pokračuji." (CATLIN 1967: 42)

23 David Dawson Mitchell (1806-1861), komisař Indian Affairs v St. Louis, jenž byl aktivním obchodníkem s indiánskými kmeny v letech 1830-1840 v horním povodí řeky Missouri. Ve třetím svazku Schoolcraftova etnografického díla o indiánských kmenech doslova napsal, že Catlinem popsané výjevy „existovaly téměř výhradně v plodné představivosti tohoto gentlemana“ (CATLIN 1967: 20).

24 Henry Rowe Schoolcraft (1793-1864), americký pro-otrokářský geograf, geolog a etnolog vydal v 60. letech 19. století publikaci o severoamerických indiánech Indian Tribes of the United States (1851-1857), v níž Catlina obvinil z „velmi bujné představivosti“, Catlin cituje Schoolcrafta v dopise Wied-Neuwiedovi (CATLIN 1967: 22). Oženil se s Jane Johnstonovou, dcerou skotsko-irského obchodníka s kožešinami a odžibvejské matky. Naučil se odžibvejsky a v roce 1847 byl kongresem požádán o zpracování knihy Indian Tribes of the United States (1851-1857, vyšla původně pod názvem Historical and Statistical Information Respecting the History, Condition and Prospect of the Indian Tribes of the United States).

25 James Kipp obchodoval s Mandany a naučil se jejich jazyk. Roku 1823 založil v blízkosti Mandanů pevnost pro Columbia Fur Company, roku 1831 založil základnu Fort Clark, do níž o rok později přijel Catlin. Více viz (WOOD 2011).

26 Narodil se 1. června 1901 ve Sanfardu v Novém Skotsku. Bakalářský titul získal na univerzitě v Beloitu ve Wisconsinu roku 1928, doktorát obhájil roku 1948 na univerzitě v Chicagu. Věnoval se výzkumu indiánských komunit v oblasti Coeur d'Alene v Idaho a byl členem Americké antropologické asociace. Byl profesorem a předsedou katedry archeologie na Satnislaus State College v Turlocku v Kalifornii. 
a ceremoniální organizace Hidatsů, 1965). Jelikož 80 \% populace Mandanů zemřelo roku 1837 během epidemie neštovic ${ }^{27}$ a rituál se poté proměnil, ${ }^{28}$ přinášejí nejpůvodnější zprávy o jeho průběhu ti, kteří Mandany navštívili před rokem tragédie, a sice Wied-Neuwied (1834) a George Catlin (1832):

\begin{abstract}
Mandanové mají rozličné léčitelské slavnosti, mezi nimiž jsou pozoruhodné okipa, aneb připomenutí pokání archy. Slaví se z jara nebo v létě a já sám je bohužel nemohu popsat jako očitý svědek. Malír Catlin z New Yorku je viděl a v novinách mu o tom vyšla krátká zpráva, kterou přikládám ke knize. Toto vyprávění je zatím neúplné, nebot [jeho] autor všem souvislostem věci neporozuměl, jak mi potvrdil také pan Kipp a další současníci; chtěl bych také podat obsáhlý popis daného, jak jsem tajemství tohoto národa slyšel od jeho zasvěcenců. (WIED-NEUWIED 1839: 72)
\end{abstract}

\title{
Moderní vývoj body suspension
}

Tělesné zavěšování ve své moderní (od šedesátých let minulého století) a současné (od devadesátých let) podobě představuje různá pojetí re-enactmentu iniciační a liminální fáze mandanského obřadu okipa - nebo se jim alespoň formálně velmi podobá. Z historiografického hlediska můžeme akce rozdělit na ty pořádané před rokem 1992 a po něm, kdy se fenoménu tělesného zavěšování ujímají specializované skupiny, jejichž členové si osvojují také zdravotnické znalosti nezbytné pro praktikování rituálu. První etapu vývoje body suspension nazvěme průkopnickou, druhou institucionalizovanou. Průkopnická etapa zahrnuje první experimenty se závěsy mezi předchůdci moderních primitivů, subkultury, vycházející z punkového a skinheadského hnutí, především však samostatné závěsy Fakira Musafara, ale také pozdější Stelarcovy závěsy ze sedmdesátých let, jež byly veřejností vnímány v rámci kategorií body artu. Organizované závěsy zahrnují workshopy i veřejná vystoupení tvůrců body suspension.

Z formálního hlediska lze akce rozdělit na a) individuálnî29 (první závěsy Fakira Musafara, první závěs Allena Falknera), b) komorní (závěs, jemuž jsou kromě viselce přítomni 1-3 lidé), c) workshop a d) vystoupení. Komorní závěsy jsou předstupněm pro organizované skupiny tělesného zavěšování, jež vznikají v devadesátých letech; prvními diváky se stávají asistenti viselce. Workshopy jsou pořádány od devadesátých let minulého století a jsou určeny pro zájemce, kteří chtějí závěs podstoupit pod dohledem odborníků. Vystoupení, zvaná suspension events, mají rozličné podoby; jejich estetika navazuje často na estetiku cirkusu či freak show ${ }^{30}$ či BDSM vystoupení.

27 „Pět let před ničivou epidemií neštovic navštívil Catlin Mandany v jejich malebné vesničce tvořené zemnicemi nedaleko obchodní základny Fort Clark, u ústí Knife River v dnešní Severní Dakotě.“ (CATLIN 1967: 1)

28 Např. klesl počet bizoních tanečníků, adeptů závěsu apod.

29 Individuální závěsy jsou charakteristické tím, že z nich existuje minimum záznamů. Záznamy jsou především fotografie vzniklé samospouští.

30 První freak show se staly populárními v Anglii již v polovině 16. století. Lidé s tělesnými anomáliemi začali být vystavováni jako objekty zájmu a zábavy davům. Slavným př́kladem raného novověku byla exhibice na dvoře Karla I., chlapců Lazara a Joanna Baptisty Colloredových (1617-1646), dvou siamských dvojčat typu Thoracopagus parasiticus z Janova. Joannes byl zřejmě prvním doloženým přeživším parazitujícím dvojčetem. 


\section{Fakir Musafar}

Fakir Musafar se narodil 10. srpna 1930 jako Roland Loomis v Aberdeenu v Jižní Dakotě a ve čtyřech letech prožil iniciační zážitek, formující u něj uvědomění si minulých životů (BROWN a NOVICK 1997). Svůj raný život zasvětil vyhledávání a navozování pozměněných stavů mysli prostřednictvím tzv. body plays. Do těch spadaly různé formy svazování, sebepoškozování a obnovování starých praktik a cvičení jogínů a fakírů. Svůj první piercing provedl spontánně ve věku 12 let ${ }^{31}$ (JURY 1986) a o rok později si udělal piercing předkožky (VALE a JUNO 1989: 9). Svou podivuhodnou automutilační tvorbu až do osmdesátých let skrýval před veřejností i svou rodinou (VALE a JUNO 1989). Jako umělec a performer, který svůj pseudonym převzal od perského fakíra Musafara ${ }^{32} \mathrm{z} R i$ pley's Believe it or $N^{2} t^{33}$, se stal ústředním představitelem moderních primitivů, ale také BDSM komunity. Inspiroval se mimo jiné v jejím prvním vlajkovém magazínu Bizarre $e^{34}$ a v tvorbě jejího vydavatele Johna Willie Couttse. Poprvé otevřeně vystoupil jako Fakir Musafar roku 1978 během Tattoo Convention v Renu. ${ }^{35}$

Svou cestu k body suspension však nastoupil již prvními experimenty v oblasti tělesných modifikací s piercingem, tightlacingem ${ }^{36}$, skarifikací a tetováním. Podle Vale Hamanaky a Andrey Juno uskutečnil Musafar na základě znalosti antropologických prací svůj první závěs roku 1966 nebo 1967 (VALE a JUNO 1989). Svou cestu k tělesnému zavěšování popsal následovně:

Začalo to v roce 1962. Bylo mi dvaatřicet let. Osud mi umožnil navštívit Japonsko. Pro začátek mé cesty velmi nepravděpodobné místo, jelikož mé kořeny jsou na pláních Jižní Dakoty, kde se mystérium zavěšování okipa objevilo před stovkami let. $\mathrm{V}$ tokijské knihovnické čtvrti Kanda jsem našel zapomenutou knihu, kterou za posledních sto let vidělo jen velmi málo lidí: původní vydání knihy George Catlina O-kee-pa, a Religious Ceremony of the Mandans. Otevřel jsem zlatem politou vazbu z červené marocké kůže. Šlo o vzácné původní vydání z Londýna nakladatelstvím Trubner \& Co., v řadě Paternoster z roku 1867!!! [sic] Držel jsem ji v rukou a listoval stránkami. Srdce mi bušilo a celé moje tělo se začalo chvět. Tady to bylo, Catlinovy litografie mandanských mladíků zavěšených za dva háky. Jak se takový poklad dostal do Japonska? Šlo o dar nějakého Brita japonskému hodnostáři, nebo jej snad ukrýval misionářský kufr? Kdo ví? Moje šance na nalezení této rarity byly jedna k miliónu, možná víc. Toho dne mne jakási síla vyšší než já nasměrovala $\mathrm{k}$ cestě do hor [...]. Záleželo na jediné věci: musel jsem uskutečnit okipa! Jenže neexistovali žádní žijící lidé, kteří by mi mohli ukázat cestu. (Suspensions $\mathcal{E}$ Tensions)

31 S čímž čtenáře seznamuje Vale Hamanaka (publikoval pod pseudonymem V. Vale).

32 Musafar byl perský súfí žijící v 19. století.

33 Ripleyho neuvěritelný svět je americká franšíza komiksů, televizní série a několika muzeí, v nichž jde především o předvádění kuriozit a př́rodních rekordů. Robert Ripley publikoval první text této série roku 1918.

34 John Willie Coutts (1902-1962) začal vydávat časopis Bizzare v roce 1946. Ten se pro 50. léta stal vlajkovou lodí komunity BDSM a fetišistů a do určité míry tak předcházel praktiky moderních primitivů.

35 Předtím vystupoval v Renaissance Faire v Los Angeles a v Ripley`s Believe It Or Not v San Franciscu.

36 Tightlacing, také zvaný corset training, je technikou úmyslného svazování korzetem za účelem tělesné modifikace. 
Musafar věnoval nějaký čas hledání vhodného průvodce svým prvním závěsem, když ale pochopil, že poslední Mandan, který mohl rituál zažít, zemřel před více než sto lety, rozhodl se uskutečnit první závěs sám. Roku 1963 si v Palo Alto v Kalifornii pomalu propíchnul kůži na hrudi ocelovými háky o průměru 1/16" (28 mm), přičemž mu tvorba piercingu zabrala několik hodin. Poté, podle svých slov, upadl do lehkého transu. Aniž by mu byl kdokoliv nablízku, postavil se na připravený sloupec knih pod závěsným rámem. Na háky se spustil plnou vahou svých tehdejších třiašedesáti kilogramů a počítal si čas. Catlin ve svém popisu poznamenává, že na dvou hácích může viselec strávit nejvýše dvacet minut a Musafar se obával, že tělo závěs nevydrží a po překročení limitu ztratí vědomí nebo si poškodí kůži. Jeho obavy však nebyly silněǰší než touha tento limit posunout, a tak zjistil, že v závěsu na dvou hácích v hrudní oblasti může viselec jeho váhy zůstat mnohem déle. $\mathrm{K}$ dalšímu závěsu se připravil až v březnu následujícího roku; ten proběhl podobným způsobem. Teprve roku 1965 se seznámil s Davym Jonesem, zkušeným tatérem tribalových vzorů, který dlouho pobýval na Západní Samoi a který projevil zájem o účast na Musafarových závěsech. V dubnu roku 1967 uskutečnil Musafar s Jonesem svůj první závěs za asistence tř̌tí osoby; Jonesův př́tel dokonce závěs zaznamenal na kameru (Suspensions $\mathcal{E} \mathcal{O}$ Tensions), Musafarův zážitek byl pro něj silně spirituální: „A tam na konci

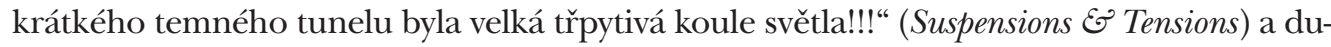
chovní rozměr tělesného zavěšování vnímá Musafar i dnes: „O sedmatřicet let později je světlo stále tu přímo nad mou hlavou." (Suspensions $\mathcal{E}$ Tensions) Do jaké míry je proklamovaná Musafarova spiritualita skutečná a do jaké se stává výrazem hledání uspokojení jeho masochistických tužeb, nelze posoudit. Jeho přístup nicméně ovlivnil řadu dalších jedinců zabývajících se fenoménem body suspension, kteří vyhledávali možnosti rozšíření vědomí prostřednictvím nevšedních tělesných zážitků v tradici fakírů či jogínů, tedy většinou směrem k smyslové deprivaci a postupného „umrtvování“ těla.

Ačkoliv záznam Jonesova př́tele se nedochoval, jeden z Musafarových závěsů je zdokumentován ve filmovém dokumentárním projektu Dances Sacred and Profane (1987) režiséra Marka Juryho. Se svým př́telem, legendárním americkým piercerem Jimem Wardem, ${ }^{37}$ tehdy Musafar před kamerou realizoval dvě akce, vycházející z rituálů prérijních indiánů. Nejprve si oba připevnili za kůži nad prsním svalem provaz a vlastní vahou se dvě hodiny pokoušeli ho přetrhnout, nebo vyrvat z kůže; jednalo se o reenactment slunečního tance prérijních Lakotů: „Uskutečníme dvě formy slunečního tance. Jimovou rolí v první části bude stát se slibujícím, slunečním tanečníkem, staneme se jimi oba. $\mathrm{V}$ tomto obřadu si propíchneme hrudě a připojíme $\mathrm{k}$ nim lano připevněné na bavlníku a při tanci za ně budeme tahat, dokud se kůže neosvobodí." (JURY 1986) Poté si Musafar protáhl připravené háky již otevřenými ranami, ${ }^{38}$ a na několik minut se za ně zavěsil na borovicovou větev.

Spustím se do závěsu a provedeme jiný druh slunečního tance, mnohem extrémnější. Vlastně se zavěsím na větev jednoho z těchto stromů a Jim bude Ka-See-Ka, bude ceremoniářem, kte-

37 James Mark Ward (nar. 28. 6. 1941) je americký piercer.

38 Musafar má za účelem závěsu na hrudi trvalý piercing. 
rý bude na celý obřad dohlížet a zajistí, abych se dostal nahoru. Když se totiž úplně odevzdáte situaci, musíte přijmout skutečnost, že se jistým způsobem odpoutáte od svého já. [...] můžete být velmi vážně zraněni, nebo můžete zemřít. Jsme tu možná sedmdesát mil od nejbližší civilizace [...]. (JURY 1986)

\section{Moderní primitivové}

Moderní primitivové, nebo též městští primitivové (urban primitives), je označení subkultury vznikající v průběhu šedesátých let minulého století, jež je úzce spojena s obnovou kmenových rituálů rozličných světových etnik v moderní euroamerické kultuře. Victoria Pitts-Taylor označuje za jejich zakladatele a duchovního otce Fakira Musafara (PITTS-TAYLOR 2008). Étos moderních primitivů je založen na odmítání současných hodnot západní civilizace (jimi chápaných a vykládaných), ale také na ekologickém odmítání destruktivních aspektů moderního kapitalismu. Mnozí z nich se pokoušejí přejímat spiritualitu, kulturní hodnoty a způsob života starověkých civilizací a etnik, jakkoli mohou být jejich vědomosti o nich nedostatečné či liché a pokusy o napodobení tím pádem nedokonalé.

Pokoušejí se, někdy s příslušnou naivitou, někdy se skutečnou snahou o porozumění povaze své kulturní apropriace, vytvářet alternativní, viditelně odlišnou a politicky radikální kontrakulturu, v níž jsou tělesné modifikace sociální, duchovní a politickou formou vyjádření. Jejich pokus o návrat k „původnímu“ stavu společnosti či lidských individuí je však utopický. Samotná idea návratu v sobě totiž zahrnuje reflexi, tedy intelektuální akci, která popírá koncept jednoduchosti založený na jakési „původní“ lidské „přirozenosti“. Aktem rozumu nelze dospět k mysli, jež by byla rozumem nepoznamenaná (takový zenbudhistický problém). ${ }^{39}$

Vale Hamanaka, americký spisovatel japonského původu, o nich píše na konci osmdesátých let: „Modern primitives ohledávají současnou živoucí záhadu: rostoucí kříšení vysoce vizuálních (a občas šokujících) ,primitivních“ praktik tělesných modifikací; tetování, mnohonásobný piercing a skarifikaci." (VALE a JUNO 1989: 4) Pojmem modern primitives se jeho autor pokusil vystihnout snahy členů vznikající subkultury o napodobování a přejímání zvyků a jednání členů společenství předliterárních kultur: „Modern primitives je pojem, který jsem, myslím, vytvořil roku 1967, když jsem potkal Buda ,Vikinga' Navarra a Zapatu v Los Angeles. Používali jsme tento termín pro označení osoby, která není členem domorodého kmene, ale naslouchá svým primitivním nutkáním a nějakým způsobem zasahuje do svého těla." (VALE a JUNO 1989: 9) Dalšími představiteli modern primitives jsou např́klad Hans Frydenlund, Mr. Sebastian, Tattoo Mike, Don Ed Hardy nebo Captain Don Leslie.

Podle fotografa a dokumentaristy hnutí moderních primitivů Chrise Wroblewského, autora publikace Modern Primitives. Von der Ästhetik der Verweigerung (1988), je tato

39 Podobný problém řešil v padesátých letech rakouský básník Oswald Wiener, když kritizoval Wittgensteinovo pojetí jazyka, neboł jeho problematiku a nedostatky řešil Wittgenstein opět jazykovými prostředky. Homo sapiens sapiens, již pro své rodové přízvisko, před racionalitou utéci nemůže. 
subkultura rozvinutím avantgardních protiburžoazních sociálních snah. Podle něj se lidé „městské džungle“ (Großstadtdschungel, WROBLEWSKI 1988) pokouší rozvíjením avantgardních tendencí odlišit od buržoazie, což postupem času převzala střední a nižší střední třída velkoměst. Pokud toto tvrzení vhodným a odpovídajícím způsobem popisovalo skutečnost na sklonku osmdesátých let, kdy Wroblewski knihu napsal, v dnešní době je již použít nelze. Vizuální komunikační rejstř́ik moderních primitivů byl téměř bezvýhradně absorbován mainstreamovou kulturou a podobným procesem prošly v euroamerické společnosti také fenomény sadismu, masochismu a bondáže.

Subkultura modern primitives se ve svých počátcích vzdalovala konzumní společnosti stř̌ední tř́ídy a vycházela $\mathrm{z}$ kořenů subkultur punku a skinheads sedmdesátých a osmdesátých let minulého století. Její prríslušníci užívali symboly boje a religiózních kultů a své fetiše otevřeně vystavovali. Prostřednictvím konceptu tělesného zraňování vystupují proti konceptu zdravého, mladého a krásného těla. Nejpohoršlivějš́ jsou v tomto směru propíchnuté nosní přepážky, tváře nebo rty a vše, co proniká do těla a vystupuje z něj. Část provokace zřejmě spočívá také v tom, že zástupce bílé euroamerické kultury adaptuje symboly a kulturní prvky vyvinuté kulturami třetího světa, čímž sám sebe vřazuje do specifické subkultury. Fyzické rozdíly děsí naši kulturu více než cokoli jiného (MUSAFAR in VALE a JUNO 1989). V minulých staletích bývaly součástí projevu antikolonialistických postojů části populace v postkoloniálních zemích.

Koncept moderního primitivismu odkazuje k provokativnímu kontrastu. [...] Avšak „primitivnost" v antropologickém smyslu je vědeckým pojmem, vztahujícím se k etnickým komunitám, které nevědí, jak psát nebo neumí používat sofistikovanou technologii, které nežijí v městské zástavbě s komplexní silniční nebo obchodní infrastrukturou. V širším smyslu je primitivnost synonymem síly a určitým druhem primární, hluboce zakořeněné vitality. (WROBLEWSKI 1988: 6)

Výše zmíněnou „primární vitalitu“ Wroblewski blíže nedefinuje, ale zdá se, že při jejím vymezení vychází z Musafarových výrokủ. Individuální diferencovanost v rámci subkultury přináší rozličné přístupy $\mathrm{k}$ pojetí těla, $\mathrm{k}$ jeho modifikaci i $\mathrm{k}$ přejímání různých prvků a tradic předindustriálních kultur. „Jejich [moderních primitivů] koncepty sama sebe jsou stejně různorodé, jako jejich způsoby sebevyjádření." (WROBLEWSKI 1988: 6) Sebevyjádření lze, podle Hamanaky a Juno, vnímat jako individuální a soukromou formu protestu vưči hodnotám majoritní společnosti: „Uprostřed téměř univerzálního pocitu nemožnosti ,změnit svět', mění jednotlivci alespoň to, nad čím mají moc. Svá vlastní těla.“ (VALE a JUNO 1989: 4) Pravděpodobně se však jedná spíše o individualismus euroamerické společnosti, potřebu (a možnost) se vyjádřit a projevit vlastní ego. Utopický výrok Hamanaky a Juno, podle něhož mají jedinci moc nad vlastními těly, tvrdě naráží na realitu totalitních systémů, které ve 20. století prokázaly, že člověk může být zbaven moci zcela libovolně, a zcela nad čímkoli. Známé je např́klad hanobení lidských těl nacisty v koncentračních táborech, přičemž vězňům s tetováním byly posmrtně tyto trvalé obrazce vyřezávány a po úpravě posloužily jako stínítka na lampy v domácnostech obergruppenführerů (RYCHLÍK 2005). Tetování ani piercing 
nejsou v současnosti projevy kontrakultury, ale spíše individuálního exhibicionismu, který může existovat v demokratickém uspořádání; napřríklad v Myanmarskét0 juntě mohli přŕslušníci punkového hnutí skončit před rokem 2010 ve vězení za odbarvené vlasy (Check out the counter-culture scene in Rangoon 2015), naopak ještě dnes se můžeme setkat s lidmi, kteří mají na předloktí vytetovaná čísla, jež získali v koncentračních táborech (označení a číslování jako performativní demonstrace ztráty moci jedince nad sebou samým, nad vlastním tělem) apod.

Součástí výrazového rejstříku moderních primitivů jsou tělesné modifikace. Od takzvaných lehkých, do nichž řadíme tetování či piercing, po těžké, jako je tatuáž očního bělma, implantáty, branding, skarifikace, ale také úprava genitálií, jako např. ampallang $^{41}$ nebo apadravya ${ }^{42}$, glansektomie ${ }^{43}$ nebo extrémní penektomie ${ }^{44}$, litoridektomie ${ }^{45}$ či odstraňování bradavek, ale objevují se také převzaté tradice stahování pasu korzetem (tightlacing, ibitoe) apod. Společensky široce přijímanými a přijatelnými formami extrémních tělesných modifikací jsou kulturistika (body building), kosmetika či estetická chirurgie.

Moderní primitivové přejímají mnohé tradiční rituály předliterárních kultur a vytvářejí z nich nové. Převzetím rituální formy a jejím zasazením do městského kontextu a nového společenství jsou na ně kladeny zcela odlišné nároky a očekávání. „Analogie mezi obsedantními ceremoniály a kultovními praktikami jsou zřejmé." (VERGINE 2000: 20) Mnozí z představitelů moderních primitivů tvrdí, že provozují ritualizované, bolestivé a krvavé praktiky v rámci hlubokého sebepoznání, spirituality a transformace blízké kulturám, z nichž jimi užívané praktiky pocházejí. Pokusy o re-enactment rituálů této subkultuře pomáhají v procesu sebepotvrzování, a zároveň mohou sloužit jako nástroj vyhraňování se vưči západní civilizaci, jejím sociálním a kulturním hodnotám. Naprosto však ztrácí úlohu, jakou hrály ve svých původních podobách a realizacích.

Ceremonie a rituály kmenové povahy jsou jedním z aspektů kýžené rituality moderních primitivů; rádi si vypůjčují rituální aspekty předindustriálních kultur a naplňují je zcela novými, specifickými významy. Ritualita, jak ji chápe Victor Turner, se však z pokusů moderních primitivů o reritualizaci a adaptaci rituálů vytrácí; často z toho důvodu, že jsou akcím přítomni diváci, kteří nejsou členy společenství, v jehož rámci rituál v původním smyslu slova probíhá.

Některé zvyky, jež moderní primitivové udržují a pokoušejí se je znovuobnovovat, si ovšem nadále podržují svou iniciační povahu: takovým aktem je například tetování nebo piercing (tyto dvě techniky patří k nejméně bolestivým z rodiny body modification, což je jeden z důvodů, proč se snadno staly součástí mainstreamové kultury). Zásadní rozdíl je však dán sociálním prostředím. Zatímco moko, obličejové tetování Maorů, prováděné

40 Nesprávně označované jako Barmské. Název „Barma“ byl zemi vnucen roku 1989 vojenskou juntou. Jedná se o supremacistické označení, nadřazující etnicitně majoritní barmánce.

41 Piercing procházející žaludem mužského přirození v horizontální rovině.

42 Piercing protínající žalud mužského přirození od jeho svrchní části ke spodní, směrem k uzdičce (frenulum).

43 Chirurgické odstranění žaludu (glans penis) mužského přirození.

44 Chirurgické odstranění penisu.

45 Chirurgické odstranění klitorisu. 
dlátem, neslo $\mathrm{v}$ maorské kultuře jasné společenské významy a jeho nositelé jím dávali na odiv své společenské postavení, v euroamerickém prostředí 20. století je obličejové tetování stále společensky stigmatizujícím prvkem.

V př́padě moderních primitivů navíc nelze hovořit o přechodovém rituálu ve van Gennepově smyslu (vnímá jej jako sociální událost, mezi něž řadí např. těhotenství, svatbu, pohřeb). Přechodový rituál (rite de passage) v jejich pojetí a interpretacích postrádá třetí fázi (zjednodušení vztahů v sociální struktuře, jedinou autoritou pro rituální subjekty se stává rituální průvodce, šaman. Původní hierarchické uspořádání mizí a nahrazuje jej absolutní rovnost mezi subjekty [Antonín Vávra] ${ }^{46}$ ), dále závěs ztrácí př́itomností diváků svou rituálnost. Jedinec, který projde liminální fází rituálu zavěšení, se nenavrací do společenství s nově nabytým statusem, nenavrací se změněný, jako někdo nový. Většinová společnost nevnímá proces závěsu jako liminální rituál a stejně tak nevnímá jedince po překročení liminální fáze závěsu jako „proměněného“. Jeho reálný sociální status zůstává nezměněn. Fakir Musafar vysvětluje význam zavěšování a rituálů obecně pro něj samotného, a tím nastiňuje také významový posun pojetí takového jednání pro současnost: „,...] prožívání těchto pozměněných stavů je tím, čím lidé vyzráva-

jí - intelektuálně, emocionálně nebo duchovně.“ (VALE a JUNO 1989: 24) Podle něj je očekávaná změna, k níž během rituálu dochází, spirituální a intimní a se společenstvím v Turnerově či Gennepově smyslu vlastně nesouvisí. Může však rituál probíhat tam, kde není společenství (communitas)? Účastníci a přítomní závěsu totiž nejsou součástí normativní ani ideologické communitas, stávají se členy pouze její existenciální formy; i to však platí pouze pro performery a aktéry vystoupení: diváci nejsou do společenstvi zahrnuti, nebot’ se rituálu aktivně neúčastní. Podle Musafara dochází k přechodu uvnitř individua, čímž dokládá, že re-enactment rituálu není v současnosti vázán na communitas a že při něm nedochází $\mathrm{k}$ liminální situaci ve van Gennepově smyslu, a tudíž nemá účel pro sociální skupinu, jako původní obřad okipa.

\section{Druhá generace body suspension}

Druhou generaci moderních primitivů i body suspension reprezentuje Allen Falkner. Narodil se roku 1969 a v roce 1992 založil skupinu TSD (Traumatic Stress Discipline), první skupinu tělesného zavěšování na světě. Inspiroval se akcemi Fakira Musafara, Stelarca a Jima Warda (Interview with Allen Falkner). TSD byla první organizovanou skupinou, která iniciovala uskutečnění SusConu (Suspension Convention), prvního velkého setkání provozovatelů tělesného zavěšování. Falkner provedl svůj první závěs roku 1992 a prvního zájemce zavěsil o rok později. Byl jím jeho tehdejší spolubydlící Ron. Zavěšen byl na rybářské háky, kterých Falkner a Ron použili asi třicet. Falkner se od roku 2007, kdy prodal svůj obchod s piercingy, věnuje především lektorství zavěšování a pořádá workshopy, na kterých se začínající skupiny učí praktikovat bezpečné závěsy. „Pokud se chcete zapojit do suspension, udělejte si průzkum. Existuje spousta informací a mnoho lidí, kteří vám

46 Liminální fáze rituálu podle V. Turnera (VÁVRA 2013). 
ochotně pomůžou. Nezkoušejte to sami. Suspension je nebezpečná činnost a měli byste ji zkoušet pouze pod dohledem školených odborníků." (Interview with Allen Falkner 2016)

\section{Stelarc}

Další důležitou osobností, která od sedmdesátých let minulého století začleňovala prvky body suspension do své tvorby, byl Stelios Arcadiou, užívající od roku 1972 jméno Stelarc. Narodil se v jihokyperském Limassolu roku 1946, avšak vyrůstal na předměstí Sunshine australského Melbourne. Jeho tvorba je specifická koncentrací na možnosti extenze lidského těla (Ear on Arm, 2007) a kyborgské experimentální projekty (Exoskeleton, 1997), i přesto však v rozmezí dvanácti let (1976-1988) uskutečnil pětadvacet různých performancí v Německu, Japonsku, USA a Austrálii, jejichž součástí byl závěs. Stelarc však málokdy zůstal u obyčejného závěsu: závěsy nebývaly vždy statické, v některých byl snímán a amplifikován tep srdce a svalové stahy. Mnoho těchto vystoupení se odehrálo v soukromých galeriích (výjimkou jsou eventy Rock Suspension, 1980 a Seaside Suspension, 1981). Další dvě vystoupení se odehrály v New Yorku (Street Suspension, 1984) a v Kodani (1985).

Tělo připoutané k ocelovým lanům bylo vyzdviženo do poloviny ramene jeřábu a posouváno směrem tam a zpět směrem ke konci, poté bylo během 24 minut trvajícího závěsu čtyřikrát otočeno o 180 stupňů, nepřetržitě rozechvíváno větrem, občas se zhouplo a otočilo podél své osy. Nejvyšší dosažená výška těla nad ulicí byla 56 metrů. (Suspensions)

Stelarc se, na rozdíl od Musafara, nezabýval spirituálním rozměrem tělesného zavěšování a tělesných modifikací. Tento odlišný přístup je do určité míry dán věkovým rozdílem obou umělců (Stelarc je o třináct let mladší než Musafar), geografickým působením (Musafar měl mezi Mandany a prérijními indiány přátele, zatímco Stelarc s kmenovou kulturou nikdy nepřišel osobně do kontaktu), ale také Stelarcovým uměleckým zaměřením. Kruciální rozdíl v mystickém vnímání tělesnosti a závěsu pojmenovává Stelarc následovně:

Ačkoliv závěsy se zabývají fyzickými obtížemi zavěšeného těla, neobsahují ani náboženský záměr (přesah tělesnosti), touhu po šamanské moci, ani jogínské ukázky sebekontroly. Nejsou realizovány za účelem iniciačního rituálu, ani jako S\&M zkoumání fenoménů bolesti a potěšení. Pravda však je, že bolestná zkušenost boří uměle vytvořenou distinkci mezi myslí a tělem. (Suspensions)

Na rozdíl od Musafara nemá Stelarc nic společného s moderními primitivy, ani s komunitou BDSM, ačkoli právě od nich zájem o tělesné zavěšování převzal. Jeho tvorbu lze primárně vnímat především v kontextu body artu a performance, v nichž výrazně přispěl k rozšíření tělesného zavěšování mezi umělci. 


\section{Body suspension v československém prostředí}

Kořeny tělesného zavěšování $\mathrm{v}$ našem prostředí nelze sledovat až $\mathrm{k}$ počátkům československého body artu. Ačkoli v tvorbě československých akčních tvůrců, především u Petra Štembery ${ }^{47}$ (Paralelni deprivace [s křečkem], 1976, nebo Spani na stromě, 1975), se setkáváme s prvky blízkými východiskům Musafarovým i Stelarcovým (askeze, smyslová deprivace, projevy masochismu, pojetí těla jako média a pokusy o jeho extenzi), samotné body suspension se objevuje až dlouho po revolučním roce 1989. Nepřichází spolu s dobovými trendy v body artu a performance artu, ale se vstřebáváním subkultury moderních primitivů, a především tělesných modifikací.

V současnosti existují v České republice tři skupiny zabývající se body suspension. První skupina se pojí s osobností Míly Bugtchera a studiem Hell. Studio bylo založeno roku 2004 v pražských Holešovicích a roku 2014 se rozdělilo na dva subjekty (Studio Hell a Fallen Angel). Druhá skupina se utvořila kolem FouSage a tetovacího a piercingového studia Inkdividual (2014). Třetí skupinou je S\&M Project Sultana Sade a Majkelíny Cat (od dubna 2014), S\&M Project se tělesnému zavěšování věnuje spíše výjimečně (KUBART 2015). Skupiny zpravidla vystupují na specifických hudebních akcích (Obscene Extreme) ${ }^{48}$ motorkářských srazech a spíše výjimečně v klubech (např. pražský Cross).

\section{Konkluze}

Moderní primitivové demonstrují návrat k ritualitě s touhou navrátit životu spirituální rozměr a naplnit projevy akčního umění širším obsahem, než je pouhé vyvolání afektů v publiku či demonstrace vlastní tělesnosti. Ve skutečnosti jde však z jejich strany velmi často o egoistický způsob sebeprezentace a exhibicionismus. Zdivadelňování vystoupení se odehrává na nejnižší úrovni, běžné např. u sportovních utkání. Praktická magie někdejšího mandanského rituálu byla nahrazena individuálním uspokojením potřeb exhibicionismu či masochismu, čímž se změnila sociální i kulturní úloha aktu. Mandanská obět, jež byla prostředkem osvícení, nutného pro celý kmen, a náboženský rozměr rituálu byl u moderních primitivů nahrazen individuálně pojatým zážitkem, navozujícím smyslové vzrušení. V rámci body artu navazují tvůrci body suspension na určité prvky tvorby Mariny Abramović, Rona Atheyho či Franka B. Historizující pojetí body suspension se navíc v akcích objevuje v omezené míře, častější jsou konotace aktuální.

Násilí páchané během rituálu Mandanů mělo magicky garantovat integritu kmene a jeho přežití. Moderní podoba body suspension takový kontext postrádá a je spíše subverzí rituálu, než jeho plnohodnotným re-enactmentem. Suspension events jsou performancemi, při nichž nedochází $\mathrm{k}$ aktivizaci diváků a $\mathrm{k}$ jejich přeměně na aktéry,

47 Narodil se roku 1945, žije a pracuje v Praze.

48 Obscene Extreme je hudební festival, který se od roku 1999 pořádá v Trutnově. Představuje kapely žánru hardcore punk, crustcore, grindcore a death metal. Festival byl poprvé uspořádán Michalem Urbancem. 
ani k ustavení communitas. Během vystoupení sice dochází k propojení znaků rituálu i spektáklu, avšak nápodoba rituálu nevede $\mathrm{k}$ „oficiální, veřejné změně statusu či identity“ (FISCHER-LICHTE 2011: 17). Vyprázdněný pojem rituál zůstává součástí slovníku subkultur, v jejichž rámci plní úlohu potvrzení skupinové identity, avšak ve většině případů nepřekračuje hranice zážitkového naplňování smyslů performativitou bolesti.

\section{Bibliografie}

A Man Called Horse [DVD]. 1970. Režie Elliot Silverstein. USA, 1970.

BELLINGER, Andrea a David KRIEGER. 2013. Ritualtheorien: Ein einführendes Handbuch. Wien: Springer-Verlag, 2013: 474.

Benefit na útulky. SE्FM Project Official [KMP video file], záznam akce 18. 6. 2015, Cross Club, Praha 7, Tomáš Kubart, archiv autora, 2015.

BLOCKER, Jane. 2004. What the Body Cost: Desire, History, and Performance. Minneapolis: University of Minnesota Press, 2004: 162.

$B M E$ [online]. [citováno dne 6. 1. 2016]. Dostupné online na http://www.bme.com/.

BME Encyclopedia [online]. [citováno dne 6. 1. 2016]. Dostupné online na http://wiki.bme.com/ index.php?title=Main_Page.

BOWERS, Alfred W. 1950. Mandan Social and Ceremonial Organization. Lincoln: University of Nebraska Press, 1950: 407.

BROWN, David Jay a Rebecca McCLEN NOVICK. 1997. Voices from the Edge. London: Freedom Press, 1997: 312.

CATLIN, George. Letter dated 12. August 1934. New-York Commercial Advertiser, 20.2., nestr., 1833.

CATLIN, George. 1867. O-kee-pa: A religious ceremony and other customs of the Mandans. Philadelphia: J. B. Lippincott and co., 1867: 52.

CATLIN, George. 1967. O-kee-pa: A religious ceremony and other customs of the Mandans. New Haven: Yale Univ. Press, 1967: 107.

COLLIER, Emilly. 2013. Spectator as Spectacle: Fakir Musafar's Assimilation of Cross Cultural Body Practice. Diplomová práce [Final Thesis]. School of the Art Institute of Chicago SAIC Chicago. Chicago: School of the Art Institute of Chicago, 2013: 134.

Dances sacred and profane [DVD]. 1986. Režie Mark Jury. USA, 1986.

DEMALLIE, Raymond a William C. STURTEVANT. 2001. Handbook of North American Indians: Plains. Washington: Government Printing Office, 2001: 577.

FISCHER-LICHTE, Erika. 2011. Estetika performativity [Aesthetics of Performativity]. Mníšek pod Brdy: Na Konári, 2011: 336.

GENNEP, Arnold van. 2013. The Rites of Passage. New York: Routledge, 2013: 208.

CHALUPECKÝ, Jindřich. 1990. Na hranicich uměni [On the Border Of Art]. Praha: Prostor, 1990: 163.

Interview with Allen Falkner. FRRRKguys: Male beauty, body art E゚ body modification culture [online]. São Paulo: FRRRKguys.com.br, 2016 [citováno dne 6. 1. 2016]. Dostupné online na http://www.frrrkguys.com.br/interview-with-allen-falkner/. 
KAPROW, Allan. 1966. Assemblage, environments E happenings/text and design by Allan Kaprow; with a selection of scenarios by: 9 Japanese of the Gutai Group, Jean-Jacquese Lebel ... [et. Al.]. New York: H. N. Abrams, 1966: 341.

Kataragama: A God for All Seasons [VHS], 1973. Z cyklu [From cycle] Disappearing World, Režie Charlie Nairn, UK, 1973.

KILLACKY, John. 2014. Blood sacrifice. American Theatre Magazine 31 (2014): 1: 112.

KUBART, Tomáš. (rozhovor - Sultan Sade) [interwiew - Sultan Sade]. Praha, vinárna U Sudu ve Vodičkově ulici, 24. 4. 2015 [Prague, vine cellar U sudu, Vodičkova Street, 24 Apr 2015].

LIBENSKÁ, Linda. 2009. The Sun Dance in the Past and Today. Diplomová práce [Final Thesis]. Pedagogická fakulta Masarykovy univerzity. Brno: Masarykova univerzita, 2009: 74.

LOWIE, Robert Harry. 1913. Societies of the Crow, Hidatsa and Mandan Indians, Anthropological papers of the American Museum of Natural History Anthropological papers. New York: The Trustees, 1913: 222.

MERTZ, Henriette. 1957. The Nephtali: one lost tribe. Madison: University of Wisconsin, 1957: 107.

MILLER, Frederic a Agnes VANDOME. 2010. Fakir Musafar. Saarbrücken: VDM Publishing, 2010: 84 .

MUSAFAR, Fakir. 1996. Body Play. In Armando R. Favazza. Bodies under Siege: Self-Mutilation and Body Modification in Culture and Psychiatry. Baltimore: Johns Hopkins University Press, 1996: 352.

MUSAFAR, Fakir. 2005. Spirit $\mathcal{E}$ Flesh: body rites $\mathcal{E}^{2}$ modifications. Uhlstädt-Kirchhasel: Arun, 2005: 168.

O'RILLEY, Sally. 2009. The body in contemporary art. London: Thames \& Hudson, 2009: 224.

PANTĚLEJEVOVÁ, Ivana. 2013. Formování identity skrze extrémní tělesnou zkušenost [Forming Identity Through Extreme Bodily Experience]. Diplomová práce [Final Thesis]. Filozofická fakulta Masarykovy univerzity. Brno: Masarykova univerzita, 2013: 42.

PITTS-TAYLOR, Victoria. 2008. Cultural Encyclopedia of the Body. Santa Barbara: ABC-CLIO, 2008: 376.

Present! [DVD]. Fakir Musafar. USA.

RYCHLÍK, Martin. 2005. Tetování, skarifikace a jiné zdobeni těla [Tatooing, Scarification, and Bodily Decoration]. Praha: NLN - Nakladatelství Lidové noviny, 2005: 352.

SMITH, Marquard a Julie Joy CLARKE. 2010. Stelarc: The Monograph. Cambridge: MIT Press, 2010: 272.

SPINDEN, Herbert Joseph a George Francis WILL. 1906. The Madans. A study of their culture, archaeology. Cambridge: Peabody Museum, 1906: 215.

STELARC. Suspensions. [online]. [citováno dne 24. 12. 2015]. Dostupné online na http://stelarc. org/?catID=20316.

Studio Hell. Praha: Studio Hell, 2016 [online]. [citováno dne 5. 1. 2016]. Dostupné online na https://hell.cz/.

„Sun Dance“. Dictionary of American History. [online]. [citováno dne 5. 1. 2016] Dostupné online na Encyclopedia.com: http://www.encyclopedia.com/doc/1G2-3401804087.html.

Suspensions \& Tensions: Today, Part I. Modblog [online]. [citováno dne 6. 1. 2016]. Dostupné online na http://news.bme.com/wp-content/uploads/2008/09/pubring/fakir/20040115.html.

TAYLOR, Colin F. 1996. Kultur und Zeremonialismus der Mandan. Braunschweig: Verlag für Amerikanistik, 1996. 
TURNER, Victor. 1969. Liminality and Communitas. In id. The Ritual Process: Structure and Antistructure. Chicago: Aldine Publishing, 1969.

VALE, Vivian a Andrea JUNO. 1989. Modern Primitives: An Investigation of Contemporary Adornment and Ritual. San Francisco: Re/Search Press, 1989: 213.

VÁVRA. Antonín. 2013. Liminální fáze rituály podle V. Turnera [Liminal Stage of Ritual According to Victor Turner]. Bakalářská diplomová práce [BA Thesis]. Husitská teologická fakulta Univerzita Karlova. Praha: Univerzita Karlova. 2013.

VERGINE, Lea. 2000. Body Art and Performance: The Body as Language, Milano: Skira Editore, 2000: 192.

WIED-NEUWIED, Maximilian zu. 1839. Reise in das innere Nord-America in den Jahren 1832 bis 1834. Coblenz: J. Hölscher, 1839: 688.

Wings of Desire [online]. [citováno dne 5. 1. 2016]. Dostupné online na http://www.wingsofdesire. org/.

WOLFERT, Jörg. 2015. Mein Körper ist das Ereignis. Wiener Aktionismus und internationale Performance: Begleitheft zur Ausstellung. Wien: Museum Moderner Kunst Stiftung Ludwig, 2015.

WOOD, W. Raymond: 2011. James Kipp: Upper Missouri River Fur Trader and Missouri Farmer. Journal of the Northern Plains 77 (2011): 1 a 2.

WROBLEWSKI, Chris. 1988. Modern Primitives. Von der Ästhetik der Verweigerung. Wien: Christian Brandstätter, 1988: 80. 


\section{Mgr. Tomáš Kubart}

Katedra divadelních studií

Filozofická fakulta, Masarykova univerzita, Brno

tomas.kubart@mail.muni.cz

Mgr. Tomáš Kubart vystudoval bakalářský a magisterský program Teorie a dějiny divadla na Filozofické fakultě Masarykovy univerzity v Brně. Zabývá se mezními oblastmi dějin divadla a umění, především teorií a vývojem akčních umění, happeningu a performance. $V$ rámci doktorského studia na brněnské divadelní vědě zpracovává problematiku vývojových předpokladů rakouského akčního umění, především Vídeňského akcionismu. V podzimním semestru 2015 přednášel na Katedře kulturní dramaturgie Slezské univerzity v Opavě, roky 2015-2017 strávil na studijním pobytu ve Vídni.

Tomáš Kubart received his MA Degree in Theatre History and Theory at the Department of Theatre Studies, Faculty of Arts, Masaryk University. His fields of interest cover interdisciplinary issues tackling the relation between theatre and arts, especially the history and theory of action arts, happening, and art performance. His Ph.D. research is targeted at Austrian Action Art, especially Viennese Actionism. In Autumn Term 2015, Kubart lectured at the Department of Cultural Dramaturgy, Silesian University in Opava; spent 2015-2017 on study stay at the University of Vienna. 